\title{
Comparison of Totally Prefabricated Bridge Substructure Designed According to Korea Highway Bridge Design (KHBD) and AASHTO-LRFD
}

\author{
Tae-Hoon Kim*
}

(Received November 10, 2012, Accepted August 8, 2013)

\begin{abstract}
The purpose of this study was to investigate the design comparison of totally prefabricated bridge substructure system. Prefabricated bridge substructure systems are a relatively new and versatile alternative in substructure design that can offer numerous benefits. The system can reduce the work load at a construction site and can result in shorter construction periods. The prefabricated bridge substructures are designed by the methods of Korea Highway Bridge Code (KHBD) and load and resistance factor design (AASHTO-LRFD). For the design, the KHBD with DB-24 and DL-24 live loads is used. This study evaluates the design method of KHBD (2005) and AASHTO-LRFD (2007) for totally prefabricated bridge substructure systems. The computer program, reinforced concrete analysis in higher evaluation system technology was used for the analysis of reinforced concrete structures. A bonded tendon element is used based on the finite element method, and can represent the interaction between the tendon and concrete of a prestressed concrete member. A joint element is used in order to predict the inelastic behaviors of segmental joints. This study documents the design comparison of totally prefabricated bridge substructure and presents conclusions and design recommendations based on the analytical findings.
\end{abstract}

Keywords: design comparison, prefabricated bridge substructure, construction periods, design method, computer program.

\section{Introduction}

Recently, various studies have been carried out abroad on the inelastic behavior and performance of precast segmental bridge columns. Precast segmental construction of concrete bridge columns is a method in which bridge columns are segmentally prefabricated off site and erected on site typically with post-tensioning (Hewes 2002; Cheng 2008; Wang et al. 2008; Yamashita and Sanders 2009; Dawood et al. 2012).

The use of precast segmental construction for concrete bridges has increased in recent years due to the demand for shorter construction periods and the desire for innovative designs that yield safe, economical and efficient structures. A shortened construction time, in turn, leads to important safety and economic advantages when traffic disruption or rerouting is necessary (Billington et al. 2001; Ou et al. 2007; Murla-Vila et al. 2012; EIGawady and Dawood 2012).

Construction Product Technology Research Institute, Samsung Construction \& Trading Corporation, Seoul 135-935, Korea.

*Corresponding Author; E-mail:

th1970.kim@samsung.com

Copyright $($ The Author(s) 2013. This article is published

with open access at Springerlink.com
Precasting allows for an increased use of high performance concrete in bridge substructures, thus improving durability. High performance concrete may be used more consistently with higher quality control in a precasting plant. In addition, the greater compressive strength of the high performance concrete is utilized to reduce the handling weight and dead load of the prefabricated bridge substructure units, thus facilitating construction (Billington and Yoon 2004; Rouse 2004; Chou and Chen 2006; Xiao et al. 2012). However, during the same period, little attention has been given to the design comparison of totally prefabricated bridge substructure. The design of a prefabricated bridge substructure, like most any other civil engineering project, is dependent on certain standards and criteria.

In this study, investigation and comparisons using codes of practices for totally prefabricated bridge substructure in Korea is done. The prefabricated bridge substructures are designed by the methods of present design [Korea highway bridge code (KHBD) 2005] and load and resistance factor design (LRFD) (AASHTO 2007). The AASHTO-LRFD has been chosen as an alternative to KHBD in design of prefabricated bridge substructure. The AASHTO Standard Specification has been accepted by many countries as the general code by which bridges should be designed.

The LRFD method has a number of advantages. It provides a more rational approach to design. Probability theory is used to establish an acceptable margin of safety based on the variability of anticipated loads and member strength. 
This study evaluates the present design method of KHBD (2005) and AASHTO-LRFD (2007) for totally prefabricated bridge substructure system. For the design, the KHBD with DB-24 and DL-24 live loads is used. The design comparison and nonlinear analysis of totally prefabricated bridge substructure systems are performed.

\section{Developed Totally Prefabricated Bridge Substructure}

This section includes summaries of the developed totally prefabricated bridge substructure system used in the study. A full description of developed prefabricated bridge substructure is given by the authors (Kim et al. 2010a, b, submitted).

Figure 1 shows the developed totally prefabricated bridge substructure systems. The ends of each column segment have a shear connection to facilitate shear transfer between segments. Shear connection also play an important role in the performance of the column segments in terms of hysteretic energy dissipation and ductility. The segments are precast with aligned ducts to allow for the threading of posttensioning strands through the column once the segments are placed in the field. The introduction of post-tensioning in the substructure has the potential to reduce residual displacements and improve joint shear performance.

The precast concrete footing system is made up of three basic types: precast concrete footing segment, headed bars with coupler and cast-in-place footings (see Fig. 1). After the shaft is drilled, spread footings or pile cap foundations at the bridge site are completed, and the precast concrete footing segment can be hauled to the site for erection. The precast footing segment is match-cast in its vertical position. Vertical casting has many advantages: formed surfaces will make up all finally visible faces of the column; the concrete can be better consolidated around the ducts; and handling will be easier, since the segments will be stored, hauled and erected in the same orientation as they were cast.

Figure 1 also shows the design concept of the precast segmental pier cap system for moderate seismic regions. Precast pier cap systems eliminate the need for forming, reinforcement, casting, and curing of concrete on the jobsite removing the precast pier cap construction from the critical path. The precast concrete pier cap segment is match-cast in its horizontal position. Connection details are developed based primarily on constructability and economic considerations.

Recent developments, although limited in number, have shown that prefabricated bridge substructures are feasible and advantageous for a wide variety of project types (see Fig. 2).

\section{Design Example}

In this design example, the investigation and comparisons using codes of practices for totally prefabricated bridge substructure are studied. The mechanical properties of the
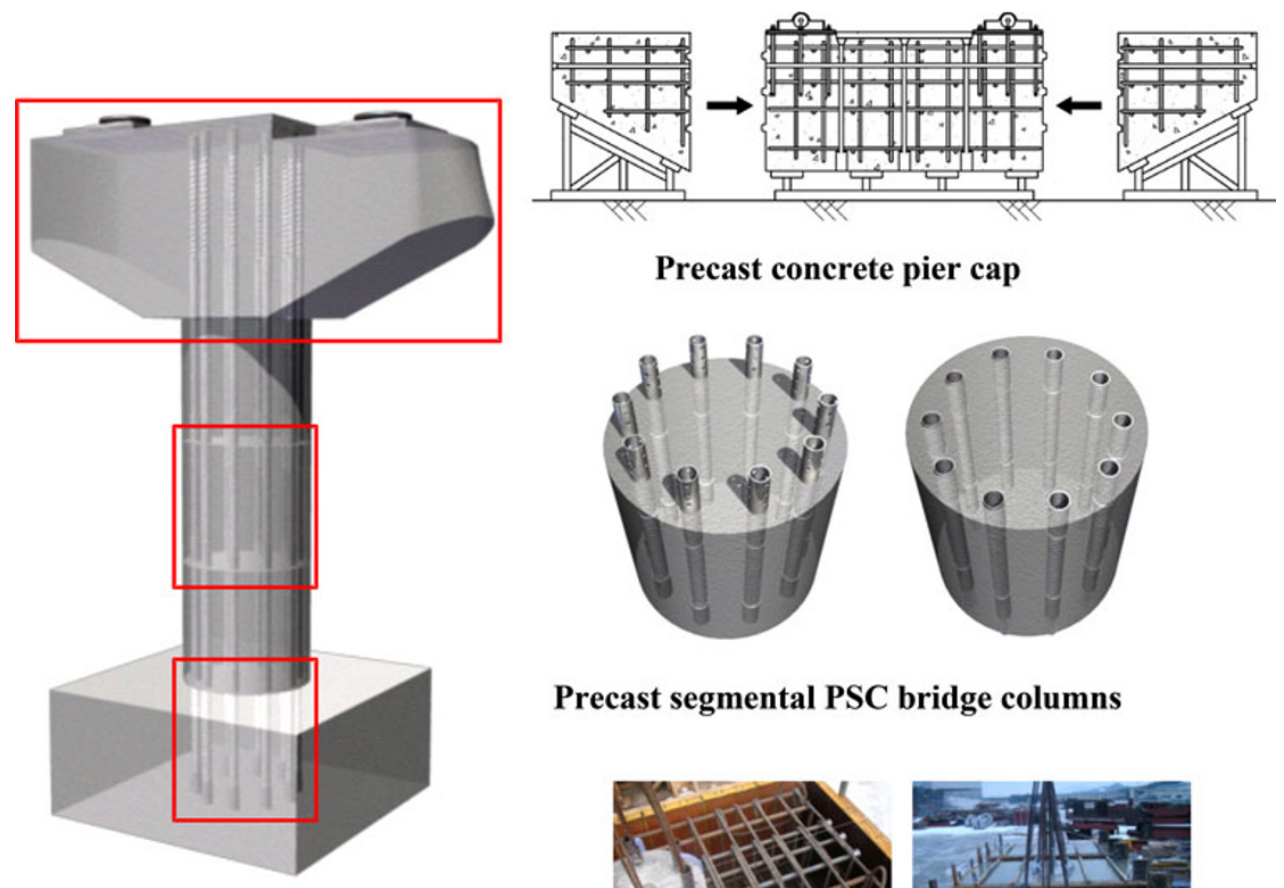

Precast concrete pier cap

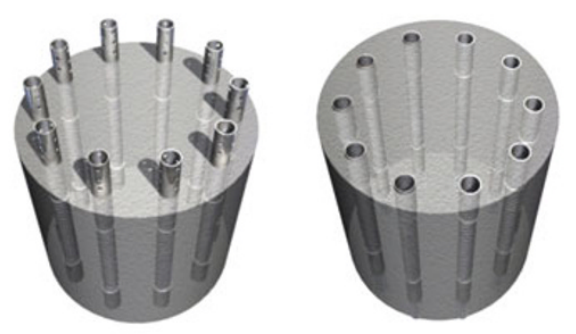

Precast segmental PSC bridge columns

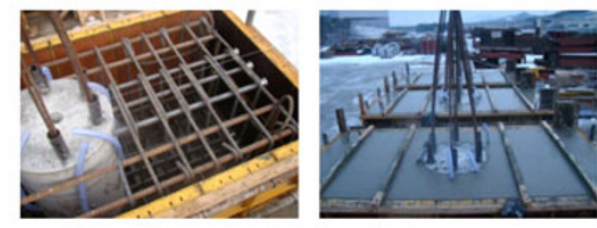

Precast concrete footings

Fig. 1 Developed totally prefabricated bridge substructure. 

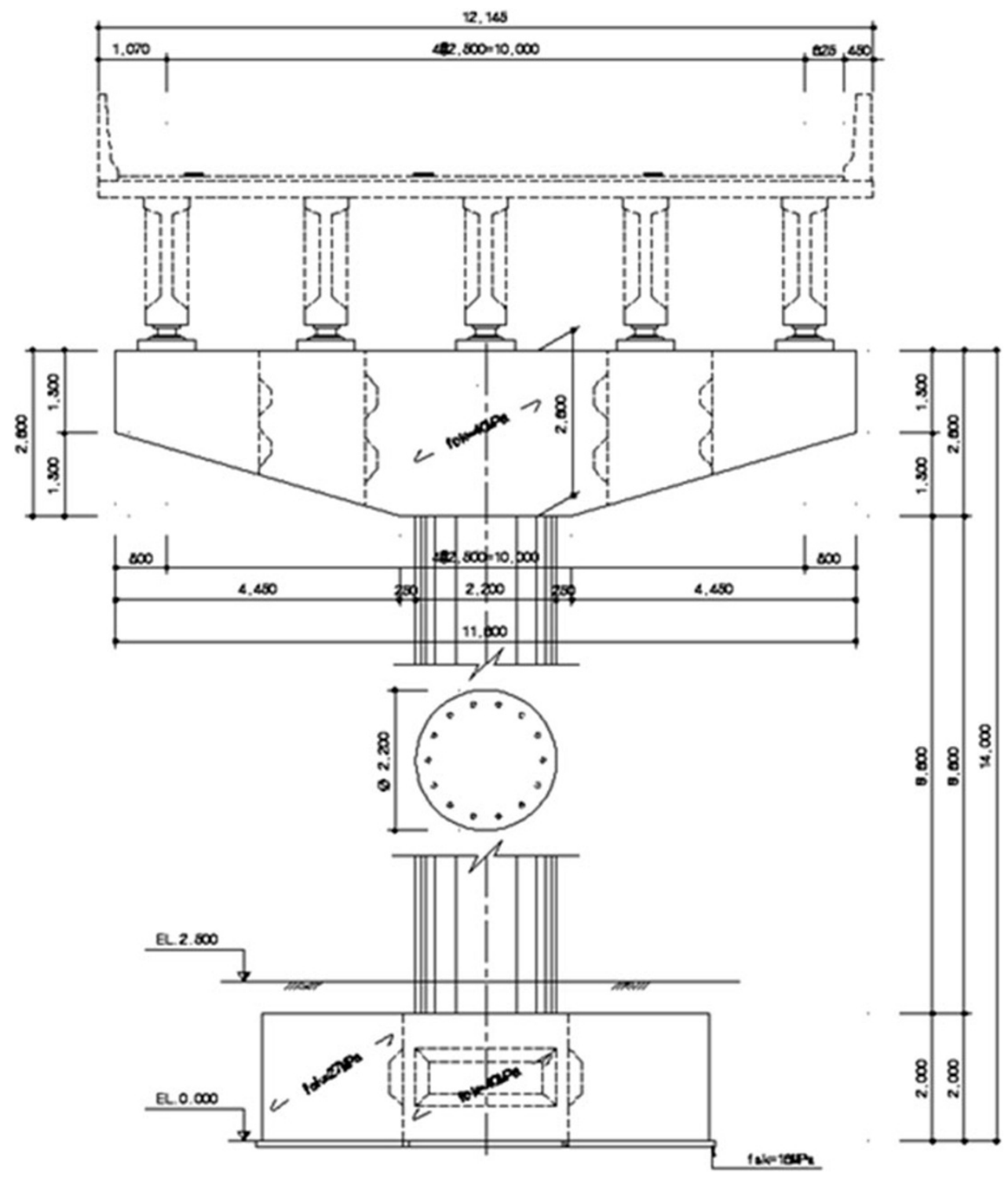

Fig. 2 Details of the design example bridge (Unit: $\mathrm{mm}$ ).

design examples are listed in Table 1 and the geometric details are shown in Figs. 2, 3, and 4.

In this study, author takes this prefabricated bridge substructure and tries redesign by using another method or code of practice to compare a size and cost of structure when using different code of practices. For this case, author select AASHTO-LRFD design code as our comparison code.

The design compressive strength of the concrete was $40 \mathrm{MPa}$. The yield strength of the reinforcement and tendon were 400 and 1,860 MPa, respectively. Author conducts this study by redesign existing prefabricated bridge substructure with a comparison code (AASHTO 2007) of practices.

Figures 5 and 6 describe the design flowchart for each code of practice for member design and overall design of totally prefabricated bridge substructure. The scopes of structure element that author has compared are pier cap, column and footing.
Each segmental column had 98 prestressing strands or 56 prestressing strands, respectively (see Table 1). The confinement steel was designed to ensure that the core concrete exhibited a sufficient ductility capacity in compression. It is considered appropriate to use the code provisions (KHBD 2005; AASHTO 2007) on the concrete confinement for the potential plastic hinge regions in the design of precast segmental columns for use in moderate seismic regions.

The precast segments of the design example were fabricated. To maximize construction speed and substructure durability, a system of match-cast segments with epoxy joints was developed. When the substructure has been assembled, post-tensioning strands are tensioned to a predetermined stress level to satisfy both service and ultimate limit state requirements for the totally prefabricated bridge substructure system (see Table 1). 
Table 1 Example properties.

\begin{tabular}{|c|c|c|}
\hline Item & KHBD & AASHTO-LRFD \\
\hline Diameter of cross section $(\mathrm{mm})$ & 2,200 & 2,100 \\
\hline Column height $(\mathrm{mm})$ & \multicolumn{2}{|c|}{14,000} \\
\hline \multicolumn{3}{|c|}{ Strength of materials } \\
\hline Concrete $(\mathrm{MPa})$ & \multicolumn{2}{|c|}{40 (Footing 27) } \\
\hline Reinforcement (MPa) & \multicolumn{2}{|c|}{ SD40 (400) } \\
\hline Shear connection $(\mathrm{MPa})$ & \multicolumn{2}{|c|}{ STK400 (235) } \\
\hline \multicolumn{3}{|l|}{ Tendon $(\mathrm{MPa})$} \\
\hline Column & 7@seven-wire strands 15.2 mm (1860)/14EA & 7@seven-wire strands $15.2 \mathrm{~mm}(1860) / 8 \mathrm{EA}$ \\
\hline Pier Cap & \multicolumn{2}{|c|}{ 7@seven-wire strands 15.2 mm (1860)/7EA } \\
\hline \multirow[t]{2}{*}{ Prestressing force $(\mathrm{MPa})$} & 929.0 (Column) & 883.7 (Column) \\
\hline & 874.0 (Pier Cap) & 832.9 (Pier Cap) \\
\hline \multicolumn{3}{|c|}{ Column } \\
\hline \multirow[t]{2}{*}{ Diameter of reinforcement } & \multirow{2}{*}{\multicolumn{2}{|c|}{$\begin{array}{c}\text { D16 (Longitudinal) } \\
\text { D22, D29 (Transverse) }\end{array}$}} \\
\hline & & \\
\hline \multicolumn{3}{|c|}{ Pier Cap } \\
\hline \multirow[t]{2}{*}{ Diameter of reinforcement } & \multirow{2}{*}{\multicolumn{2}{|c|}{$\begin{array}{c}\text { D13, D16 (Horizontal) } \\
\text { D19 (Vertical) }\end{array}$}} \\
\hline & & \\
\hline \multicolumn{3}{|c|}{ Footing } \\
\hline Diameter of reinforcement & \multicolumn{2}{|c|}{ D25, D19 } \\
\hline Cover thickness (mm) & \multicolumn{2}{|c|}{100} \\
\hline Axial force & \multicolumn{2}{|c|}{$0.1 f_{c k} A_{g}$} \\
\hline
\end{tabular}

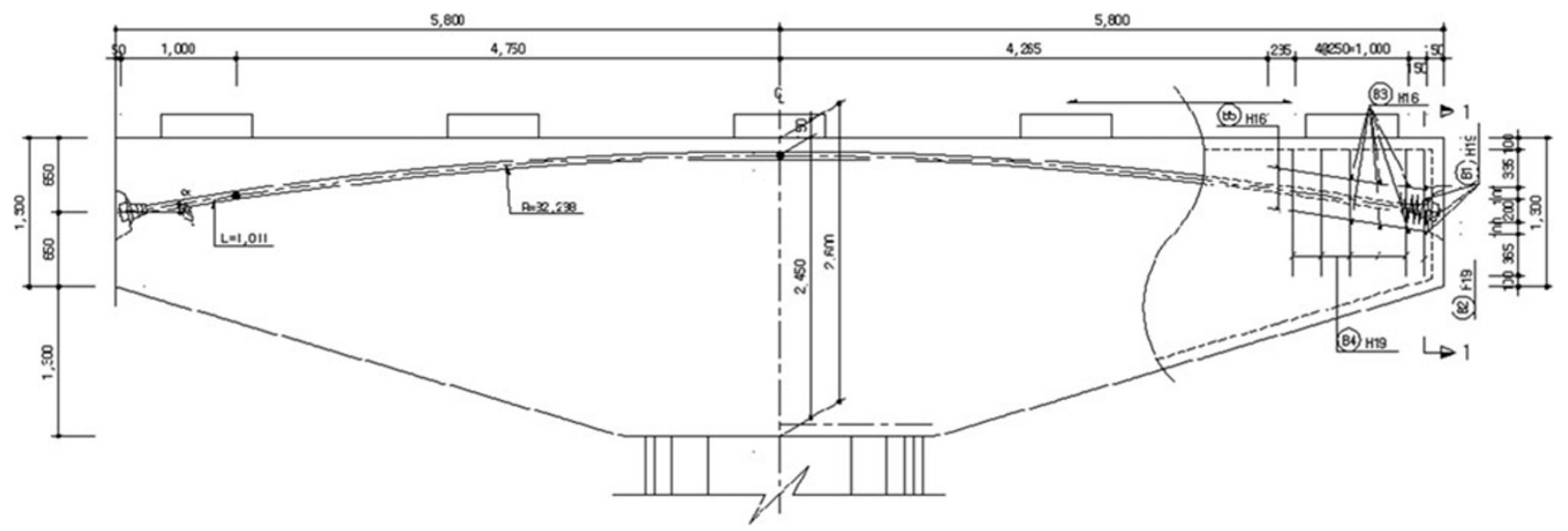

Fig. 3 Details of design example (Unit: $\mathrm{mm}$ ).

\section{Results and Analysis}

\subsection{Computational Platform for Totally} Prefabricated Bridge Substructure

An evaluation method for the performance of totally prefabricated bridge substructure is proposed. The proposed method uses a nonlinear finite element analysis program [Reinforced concrete analysis in higher evaluation system technology (RCAHEST)] developed by the authors (Kim et al. 2007, 2008, 2010a, b, submitted).

The structural element library, RCAHEST, is built around the finite element analysis program shell named FEAP, 

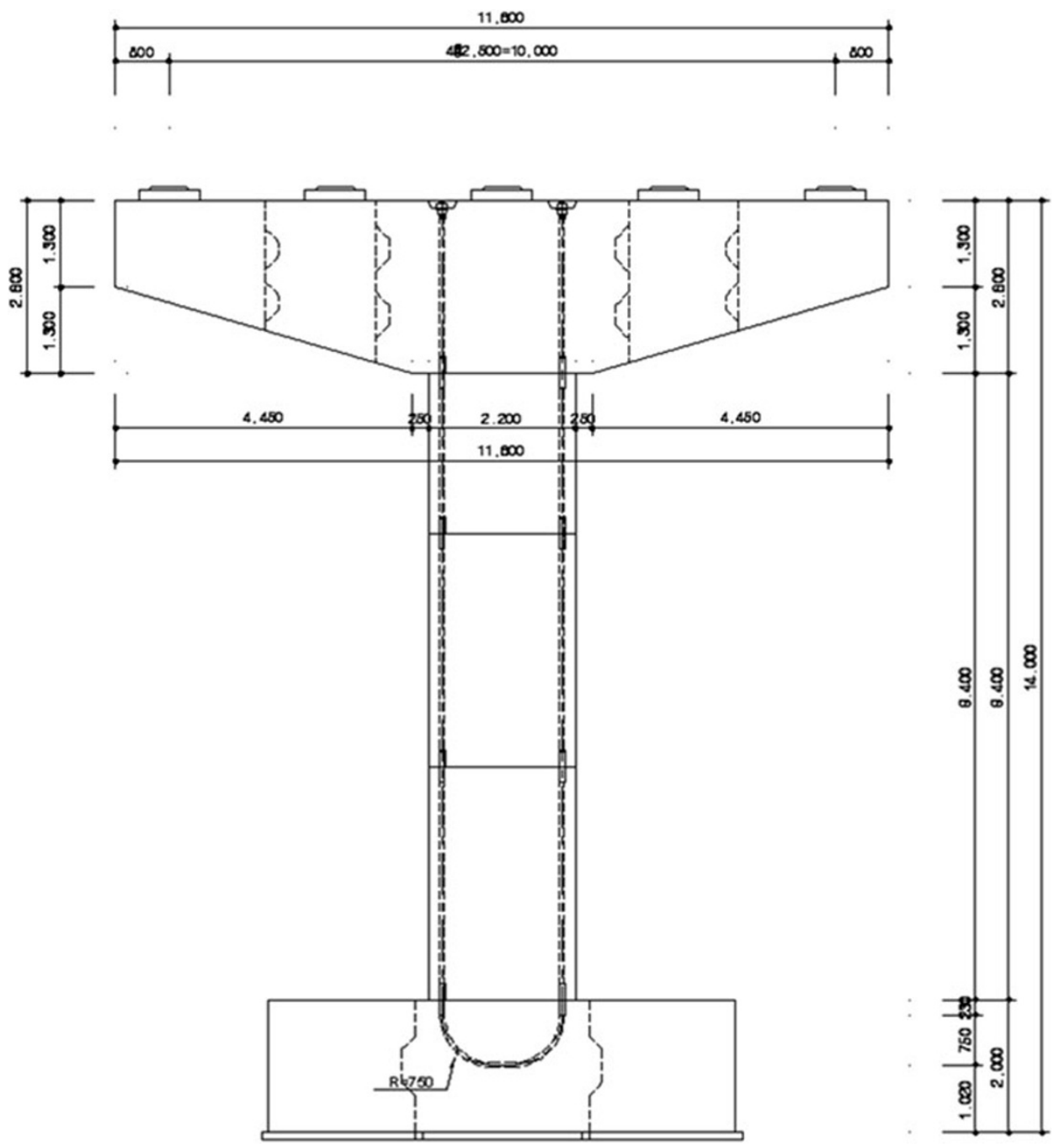

Fig. 4 Details of design example (Unit: $\mathrm{mm}$ ).

developed by Taylor (2000). The elements developed for the nonlinear finite element analyses of reinforced concrete bridge columns are a reinforced concrete plane stress element and an interface element (Kim et al. 2007, 2008). Accompanying the present study, the authors attempted to implement a bonded tendon element and a modified joint element for the segmental joints with a shear connection (Kim et al. 2010a, b, submitted).

The nonlinear material model for the reinforced and prestressed concrete (PSC) comprises models for concrete and models for the reinforcing bars and tendons. Models for concrete may be divided into models for uncracked concrete and for cracked concrete. For cracked concrete, three models describe the behavior of concrete in the direction normal to the crack plane, in the direction of the crack plane, and in the shear direction at the crack plane, respectively. The basic and widely-known model adopted for crack representation is based on the non-orthogonal fixed-crack method of the smeared crack concept (Maekawa and Pimanmas 2001). The post-yield constitutive law for the reinforcing bar in concrete considers the bond characteristics, and the model is a bilinear model. For prestressing tendons that do not have a definite yield point, a multilinear approximation may be required. In this study, the trilinear model has been used for the stress-strain relationship of the prestressing tendon. The transverse reinforcements confine the compressed concrete in the core region and inhibit the buckling of the longitudinal reinforcing bars. In addition, the reinforcements improve the ductility capacity of the unconfined concrete. This study adopted the model proposed by Mander et al. (1988) for normal strength concrete of below $30 \mathrm{MPa}$ and adopted the model proposed by Sun and Sakino (2000) for high strength concrete of above $40 \mathrm{MPa}$. An analytical model was proposed for confined intermediate strength concrete from 30 to $40 \mathrm{MPa}$ (Kim et al. 2008). The model incorporates all relevant parameters of confinement with a smooth transition from 30 to $40 \mathrm{MPa}$.

Details of the nonlinear material model used have been provided by the authors in previous research (Kim et al. 2007, 2008, 2010a, b, submitted). 


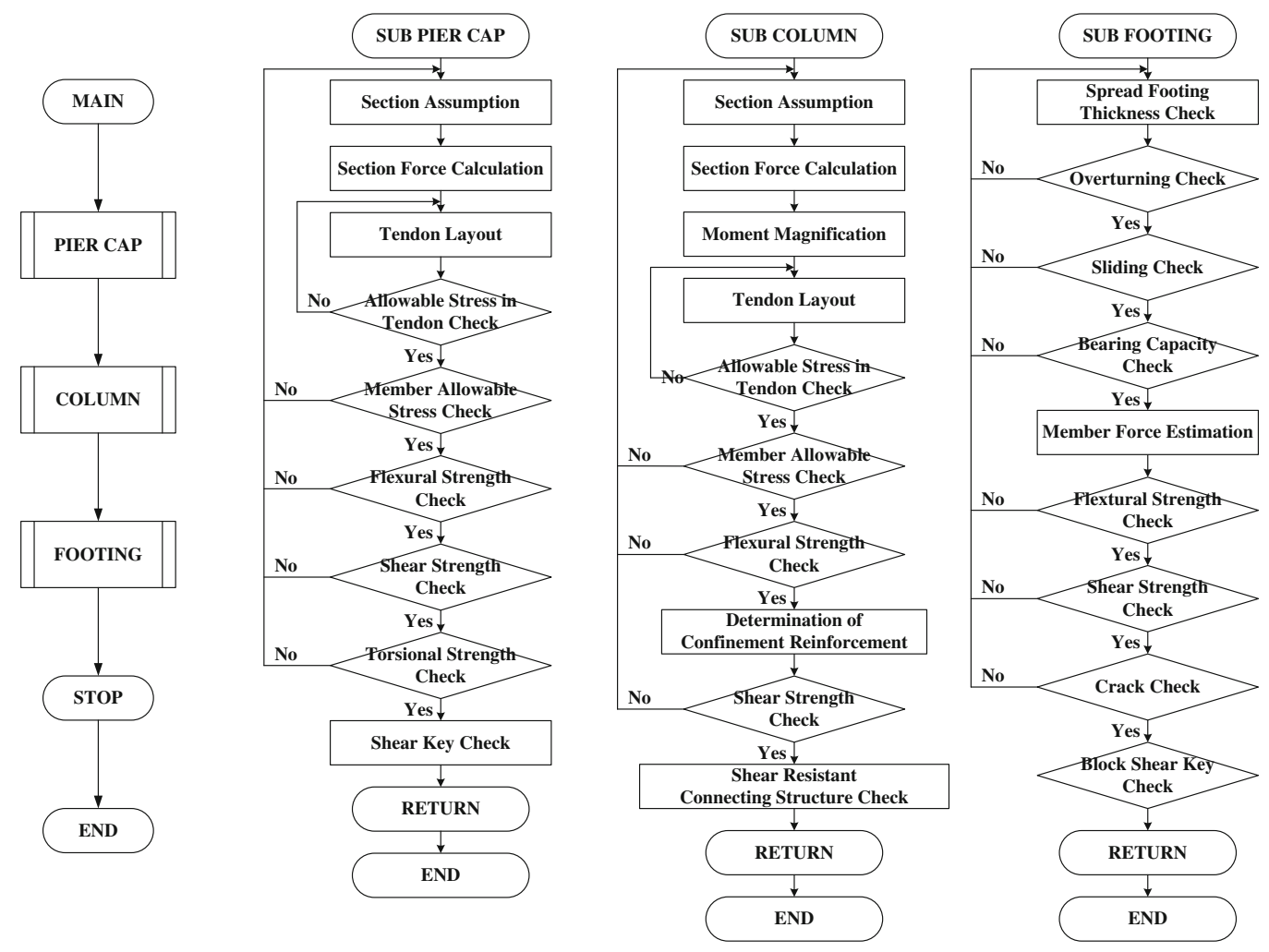

Fig. 5 Design flowchart for totally prefabricated bridge substructure (KHBD).
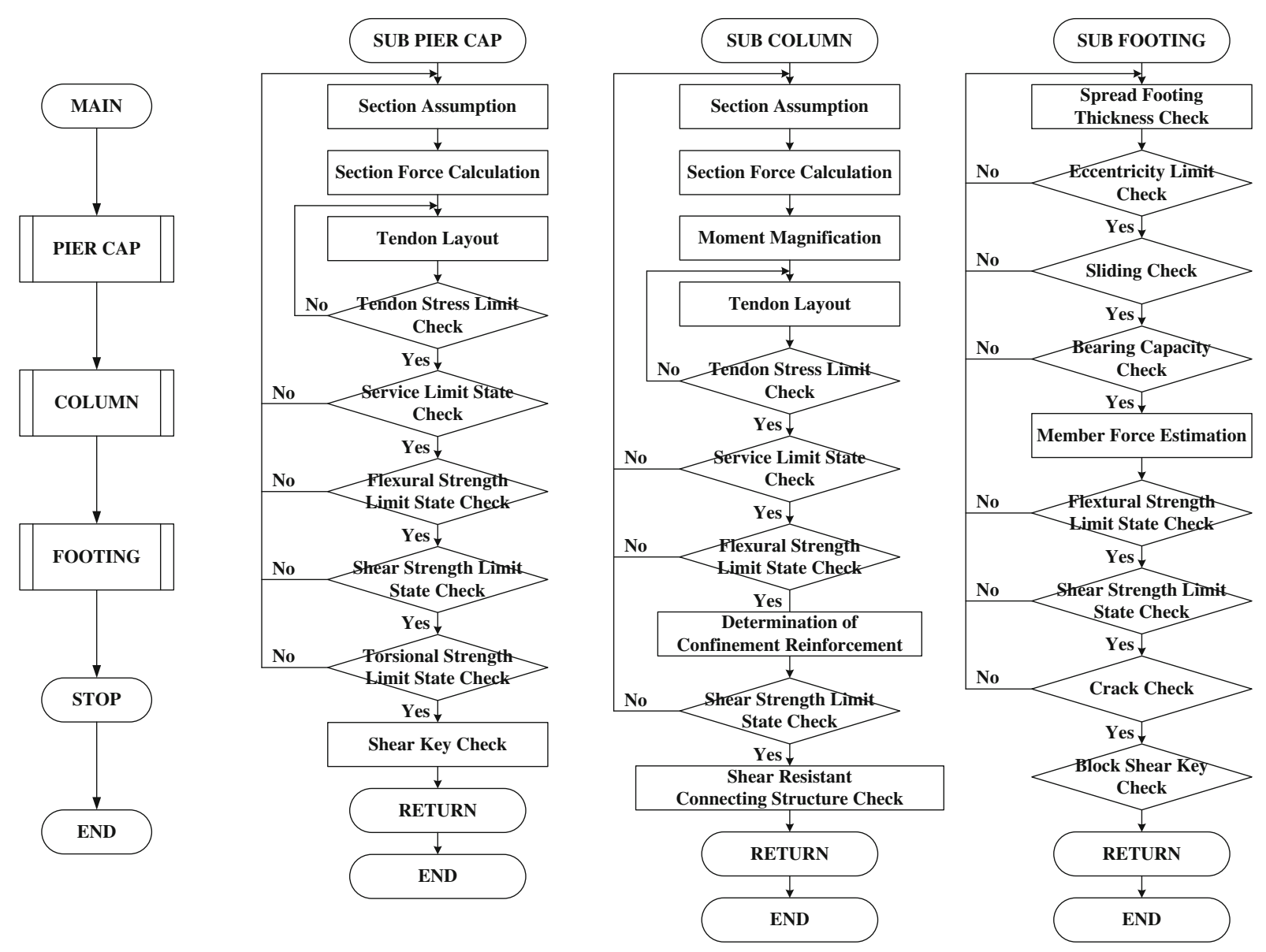

Fig. 6 Design flowchart for totally prefabricated bridge substructure (AASHTO-LRFD). 
Table 2 Comparison for different code.

\begin{tabular}{c|c|c|c}
\hline Item & KHBD & AASHTO-LRFD & Percent of difference (\%) \\
\hline \hline Concrete $\left(\mathrm{M}^{3}\right)$ & 208.1 & 204.9 & 1.6 \\
\hline Tendon (tonf) & 2.288 & 1.610 & 42.1 \\
\hline Reinforcement (tonf) & 22.999 & 22.743 & 1.1 \\
\hline
\end{tabular}
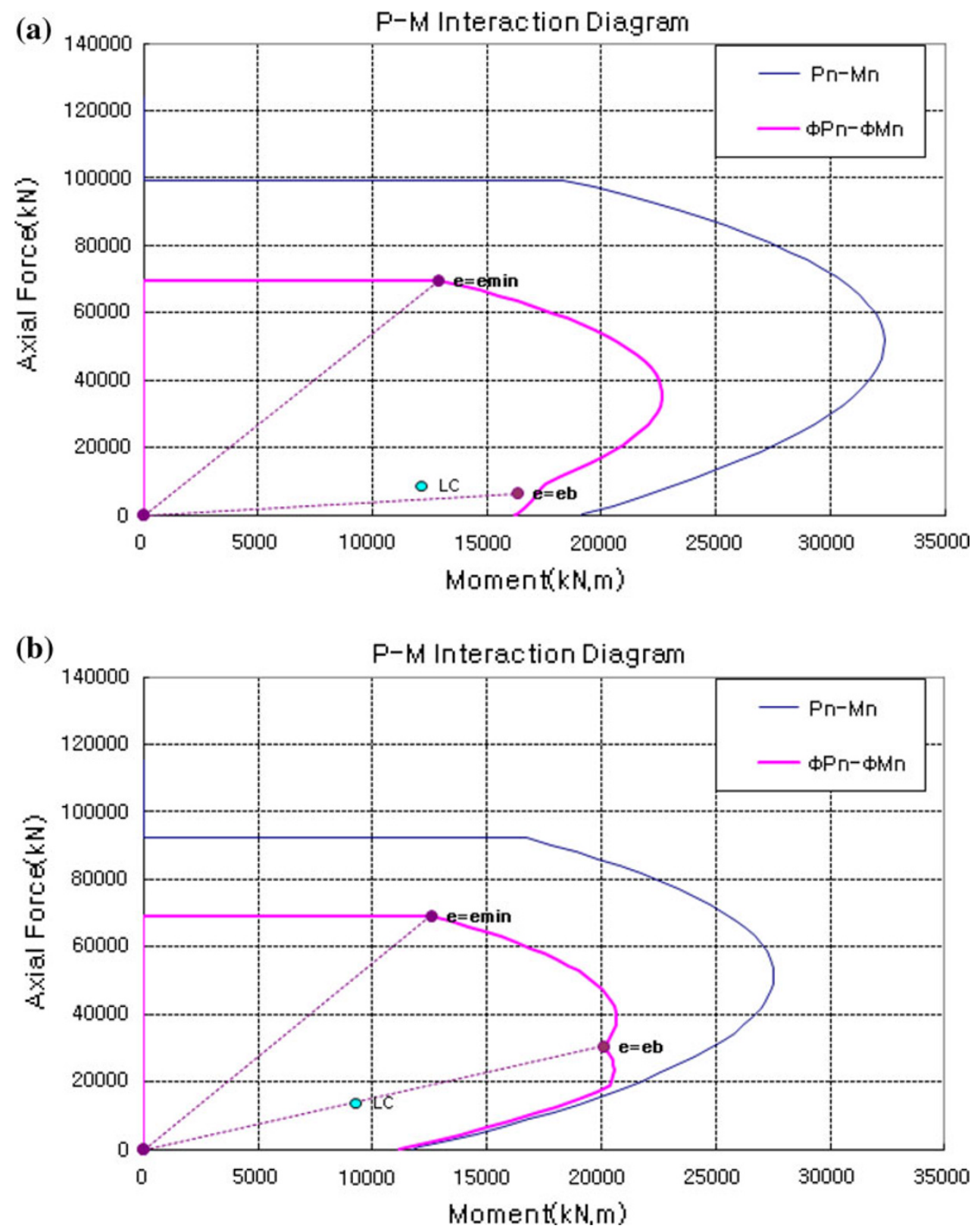

Fig. 7 Load-moment interaction diagram: a KHBD; and b AASHTO-LRFD.

\subsection{Results}

In this section, author tries to compare two codes of practice KHBD (2005) and AASHTO-LRFD (2007) for totally prefabricated bridge substructure.

Table 2 shows the value of require quantity for usage of different codes. Based on the result and analysis, author can see that cost for using different code is decrease in term of amount of tendon area if author applies AASHTO-LRFD Code.

Author can conclude that by applying AASHTO-LRFD code for prefabricated bridge substructure design it's more save than KHBD in term of Korea situation. Author can save cost. This case occurred because the wind load combinations in AASHTO-LRFD is consider to small compare to KHBD. 
(a)
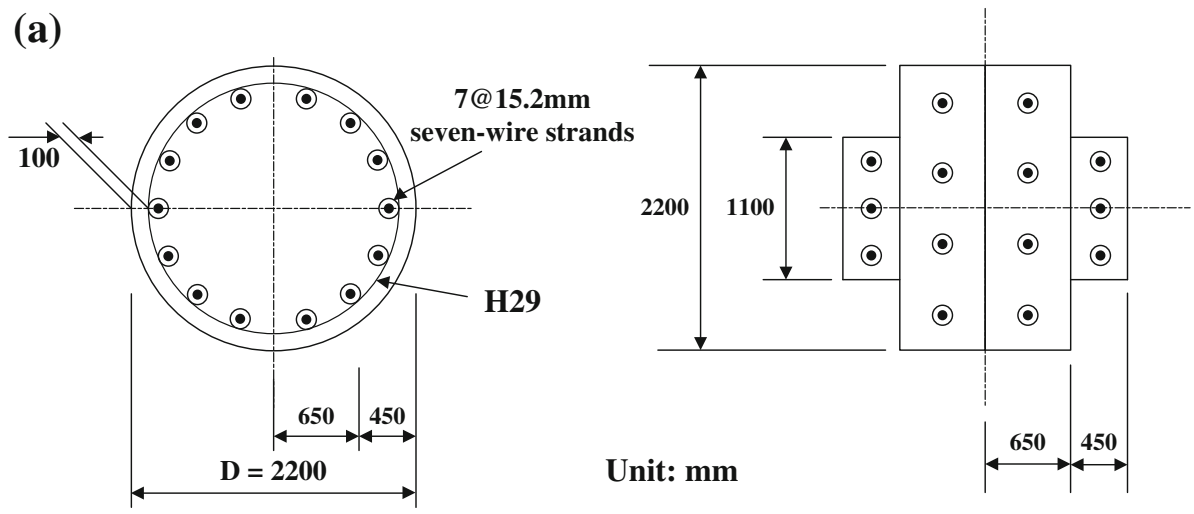

(b)

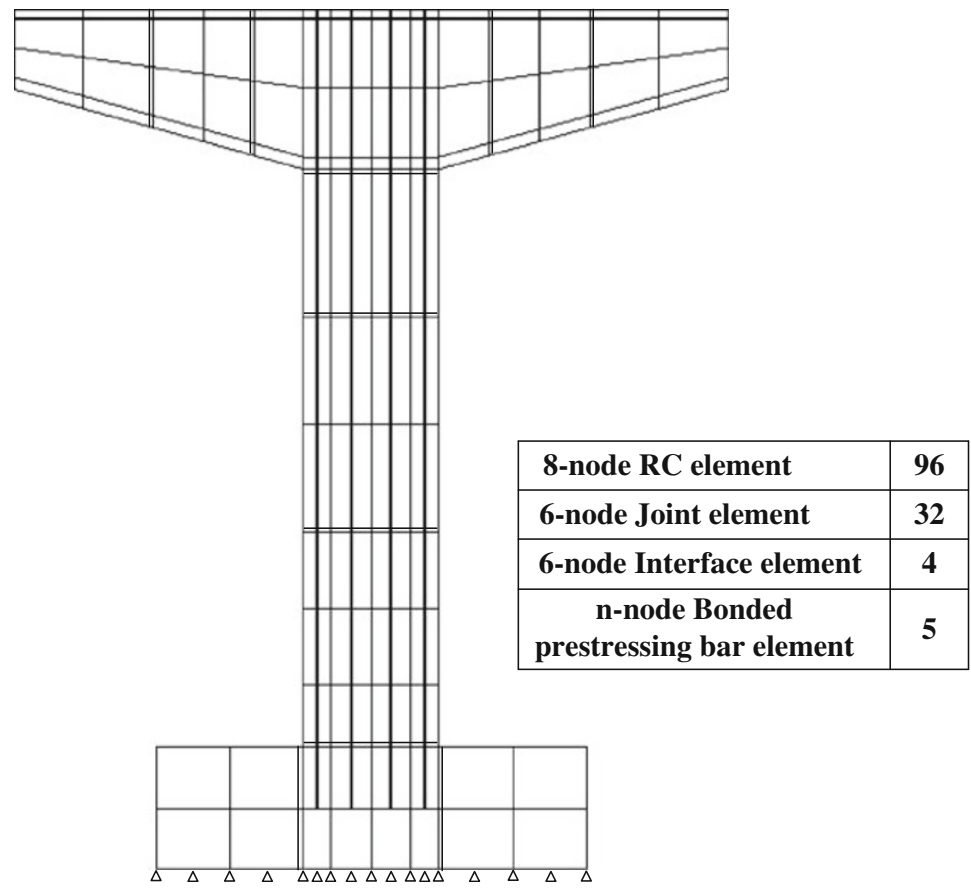

Fig. 8 Finite element mesh for design example: a transformation of a circular column to an idealized equivalent rectangular column; and $\mathbf{b}$ finite element mesh for analysis.

The wind load combination shows a $30 \%$ benefit using AASHTO-LRFD versus KHBD and collision loads were not included.

The $\mathrm{P}-\mathrm{M}$ interaction diagram for prefabricated bridge substructure in the previous section is shown in Fig. 7. The column strength is generally checked by comparing the applied axial load and the total moment with the axial forcemoment capacity of the column section. Therefore, the strength analysis of the column section may be essential to the practical design of precast segmental PSC bridge columns. Load-moment interaction diagrams presented here have been developed based on the KHBD (2005) and AASHTO-LRFD (2010) code provisions for fully prestressed concrete compression members. For the normal strength columns, the analyses provide conservative column strengths compared with the design results. The design procedure suggested here should lead to a conservative yet economically attractive design.

\subsection{Analysis}

A three-dimensional finite element analysis is tedious and expensive, and requires a high number of elements to achieve a good accuracy. Therefore, two-dimensional eightnoded smeared elements are used to model the design examples. Figure 8 shows the finite element discretization and the boundary conditions for two-dimensional plane stress nonlinear analyses of the prefabricated bridge substructure. The joints between the precast segments with a shear connection were modeled using modified six-noded joint elements. The interface elements between the precast concrete footing segment and the cast-in-place footings enhance the modeling of the effects of localized 
(a)

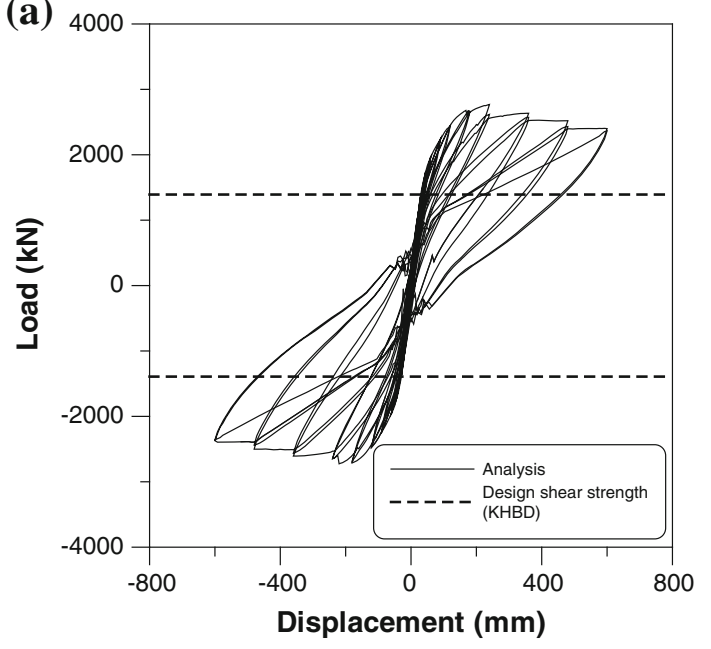

(b)

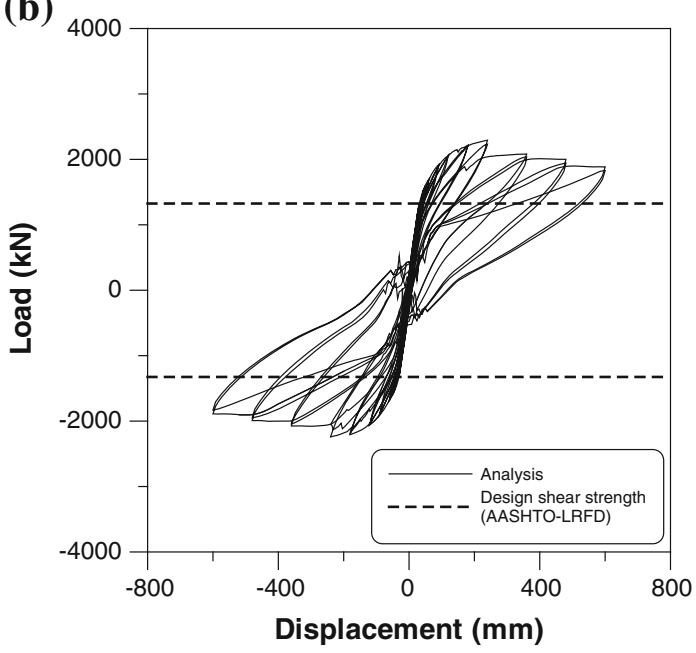

Fig. 9 Load-displacement relationship for design example: a KHBD; and b AASHTO-LRFD.

discontinuous deformation. The bonded post-tensioning tendons were modeled with two-noded truss elements that were attached at their end nodes to the concrete element nodes at the anchorage locations.

Figure 8 also shows a method for transforming a circular section into rectangular strips when using plane stress elements. For rectangular sections, equivalent strips are calculated. After the internal forces are calculated, the equilibrium is checked. In this transformation of a circular section to a rectangular section, a section with minimum error was selected through iterative calculations concerning the moment of inertia for the sectional and area of concrete and reinforcements, to ensure that the behavior was similar to the actual behavior of the segmental bridge columns with circular sections. The prefabricated bridge substructures were performed under a $0.1 f_{c k} A_{g}$ constant compressive axial load to simulate the gravity load from bridge superstructures.

The lateral load-lateral displacement response for design examples are shown in Fig. 9. The proposed analytical model predicts the load-displacement relationship of prefabricated bridge substructure with flexure failure. In terms of cyclic behavior, the simulation captures the hysteretic loops. The self-centering characteristic of the precast system is evidenced by the pinched hysteresis loops near the origin. The design examples also exhibited ductile behavior under cyclic loading. Ultimate ductility capacity can be determined as 6.3 and 5.7, with a safe design limit of 5.0, providing 26 and $14 \%$ reserve of displacement capacity. Figure 9 also shows the design shear strength of the prefabricated bridge substructures. The design shear strength obtained from the design code (KHBD 2005; AASHTO 2007) is conservative for the design example.

Figure 10 shows the failure pattern of example KHBD and example AASHTO-LRFD. Damage was concentrated only at the column-footing joint. The calculated failure sequence was similar. The final failure was due to the crushing of concrete, followed by the yielding of the tendons.

The purpose of this section is also to investigate the seismic performance of totally prefabricated bridge substructure when subjected to impulsive near fault ground motions. Figure 11 shows the acceleration record of input ground motions, which was used for this dynamic analysis. The peak ground acceleration (PGA) value for artificial earthquake is $0.391 \mathrm{~g}$ and the duration is $15.9 \mathrm{~s}$. PGA values for input load start from $0.0627 \mathrm{~g}$ and gradually increase to the failure PGA by $\sim 0.1 \mathrm{~g}$. A procedure was applied to the totally prefabricated bridge substructures by incrementally increasing the earthquake amplitudes by multiplying the acceleration time history by a scalar factor. The loading protocol used included the effects of impulsive near fault ground motions. For the numerical analysis, the author recommended using $3 \%$ critical damping.

The solution to the seismic response of prefabricated bridge substructure was obtained by numerical integration of the nonlinear equations of motion using the Hilber-HughesTaylor (HHT) algorithm (Hilber et al. 1977; Hughes 1987). The HHT method is adopted in the present implementation for the solution of the dynamic equilibrium equations. In the present study, 'Rayleigh damping' is also used, which is a linear combination of the mass and stiffness matrices. The main advantage of using Rayleigh damping is that it leads to a banded damping matrix that has the same structure as the stiffness matrix (Taylor 2000).

Figures 12, 13, and 14 show the comparison of the response time history obtained by analysis. The values given by design examples were similar. Consequently, the computed overall response to seismic motions can give efficient data for examining the required seismic performances.

The relationship between maximum shear force and displacement is obtained as shown in Fig. 15. The relative magnitudes of these residual displacements sustained by such a self-centering system are minimal compared to those expected from a conventional reinforced concrete system. The analytical solution has good agreement in linear behavior region as well as in nonlinear behavior region.

An analytical evaluation was developed to assess damage states and performance levels of solid reinforced concrete 
(a)

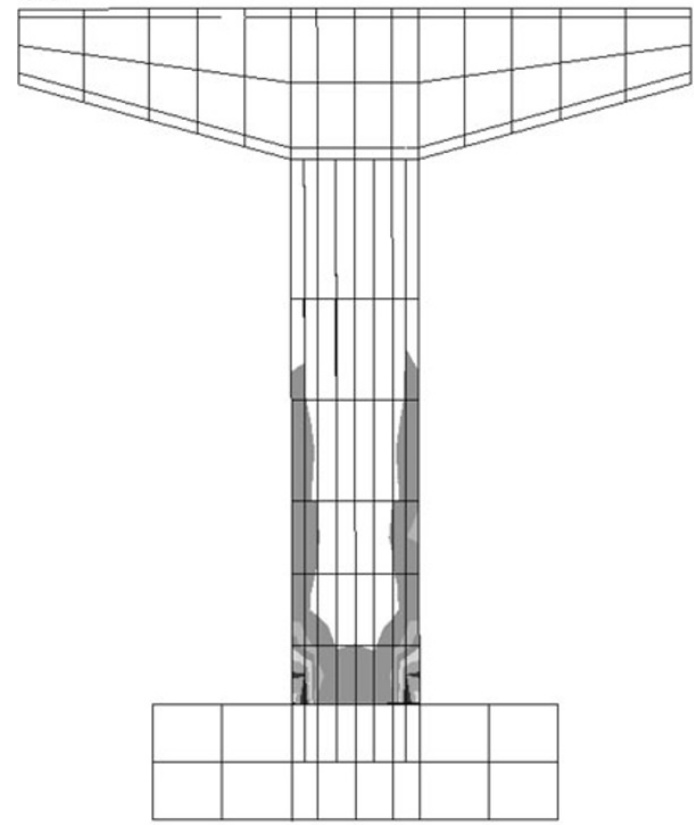

(b)

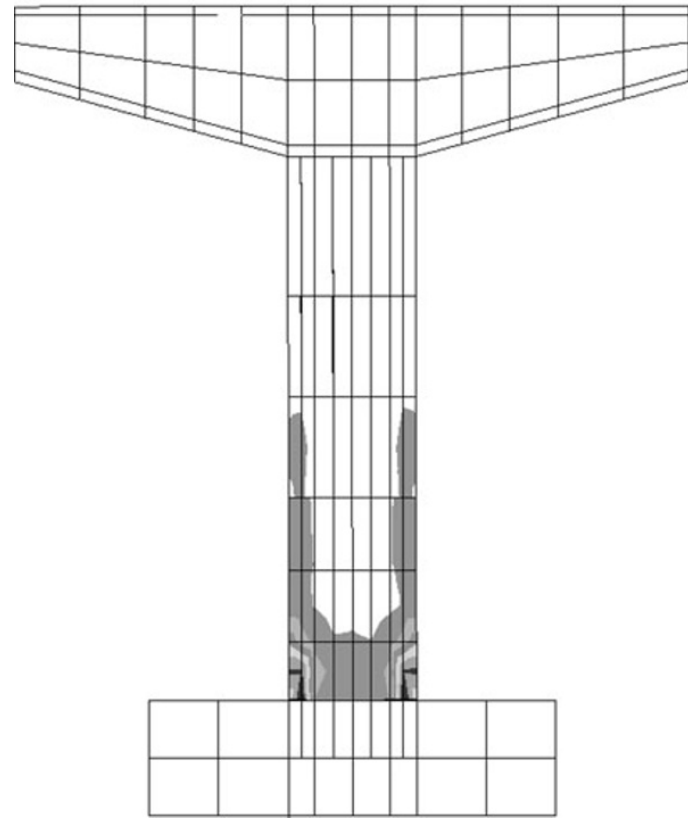

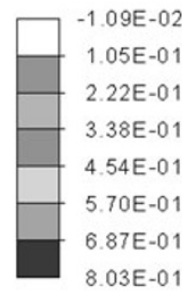

Current View

$\mathrm{Min}=-1.09 \mathrm{E}-02$ $X=-1.59 E+00$

$Y=1.38 \mathrm{E}+03$

$\mathrm{Max}=8.03 \mathrm{E}-0$

$X=4.93 E+02$

$Y=2.00 E+02$

$\operatorname{Tim} \theta=4.20 \mathrm{E}+03$

Fig. 10 Failure pattern for design example: a KHBD; and b AASHTO-LRFD.

bridge columns (Kim et al. 2007). Explicit descriptions of the different performance levels are defined to employ specific engineering criteria. Table 3 provides an example of such descriptions that might be associated with the three performance levels. For the "fully operational" performance level, the column is designed to remain almost undamaged, and repair is not required. For the "delayed operational" performance level, the column is expected to sustain some damage that impairs its full use and that might require repair. Finally, for the "stability" performance level, the column may be expected to sustain severe damage requiring partial or complete replacement of the column. This framework has been formulated in various documents on performancebased design of bridge and building structures (ATC 1996; FEMA 1997).

The proposed method predicts damage state and performance level for design examples as shown in Fig. 16. The used damage index shows a reasonable gradual progression of damage throughout the load history. These damage indices were derived from a parametric study using finite 


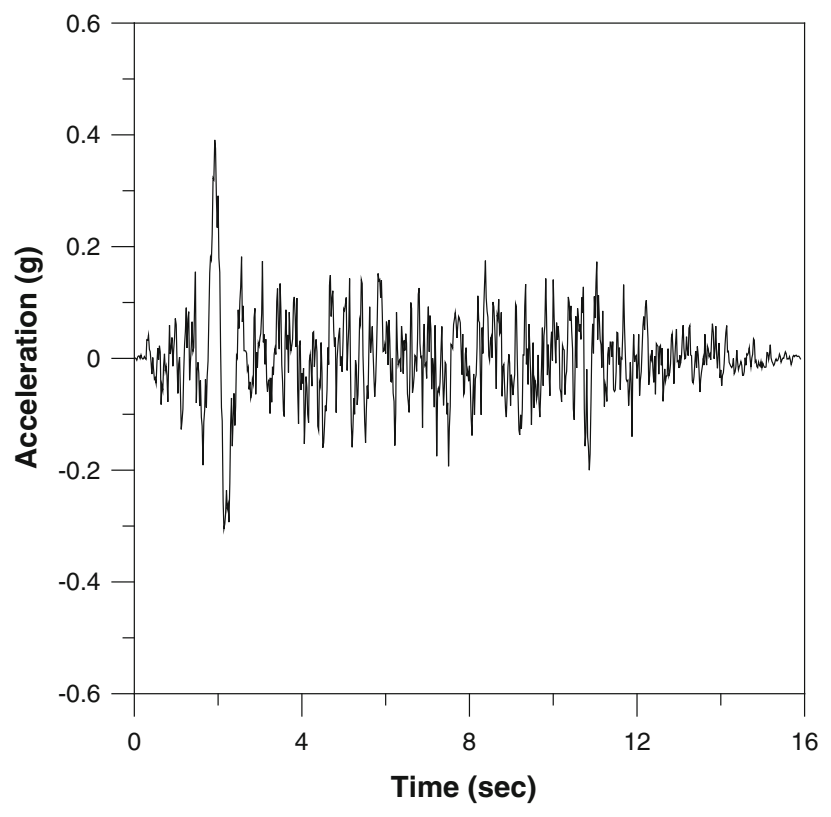

Fig. 11 Artificial near-fault ground motion.
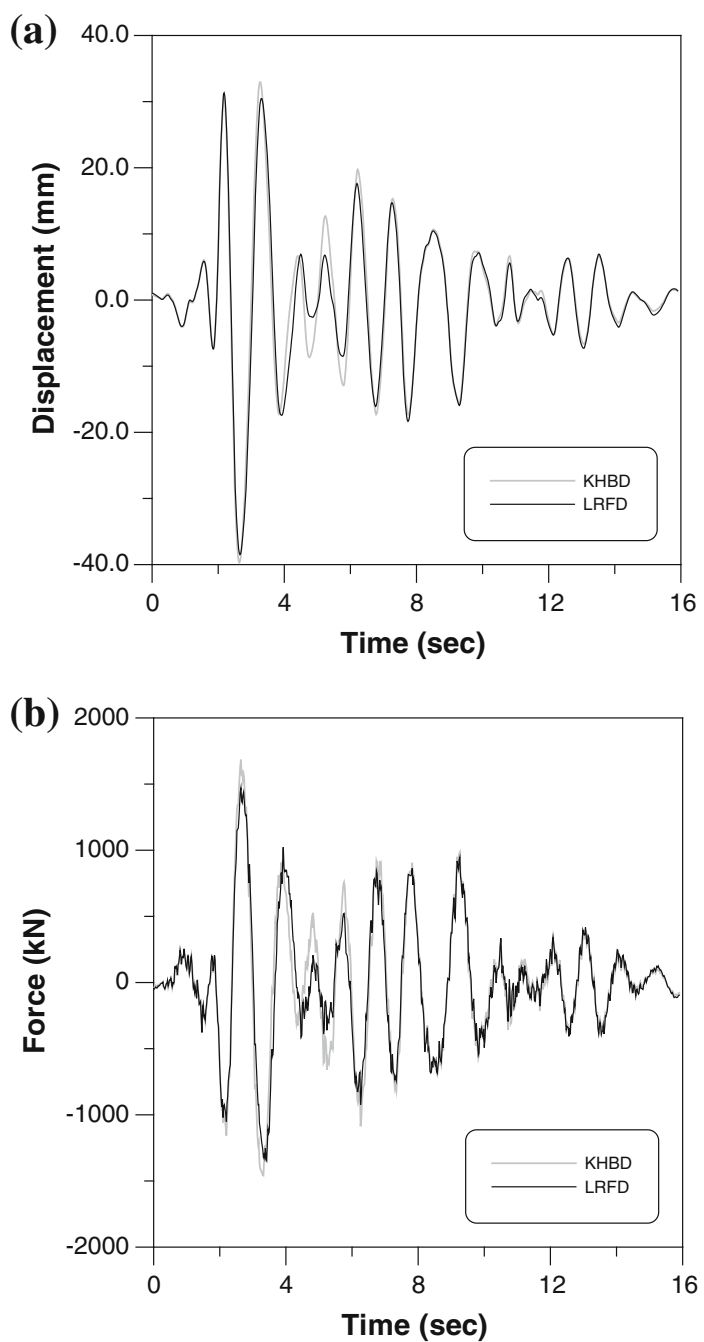

Fig. 12 Response for design example (PGA $0.154 \mathrm{~g}$ ): a displacement; and b force.

element analysis (see Table 4). It can be also seen from Fig. 16 that example AASHTO-LRFD provided the performance similar to example KHBD. The results of this study
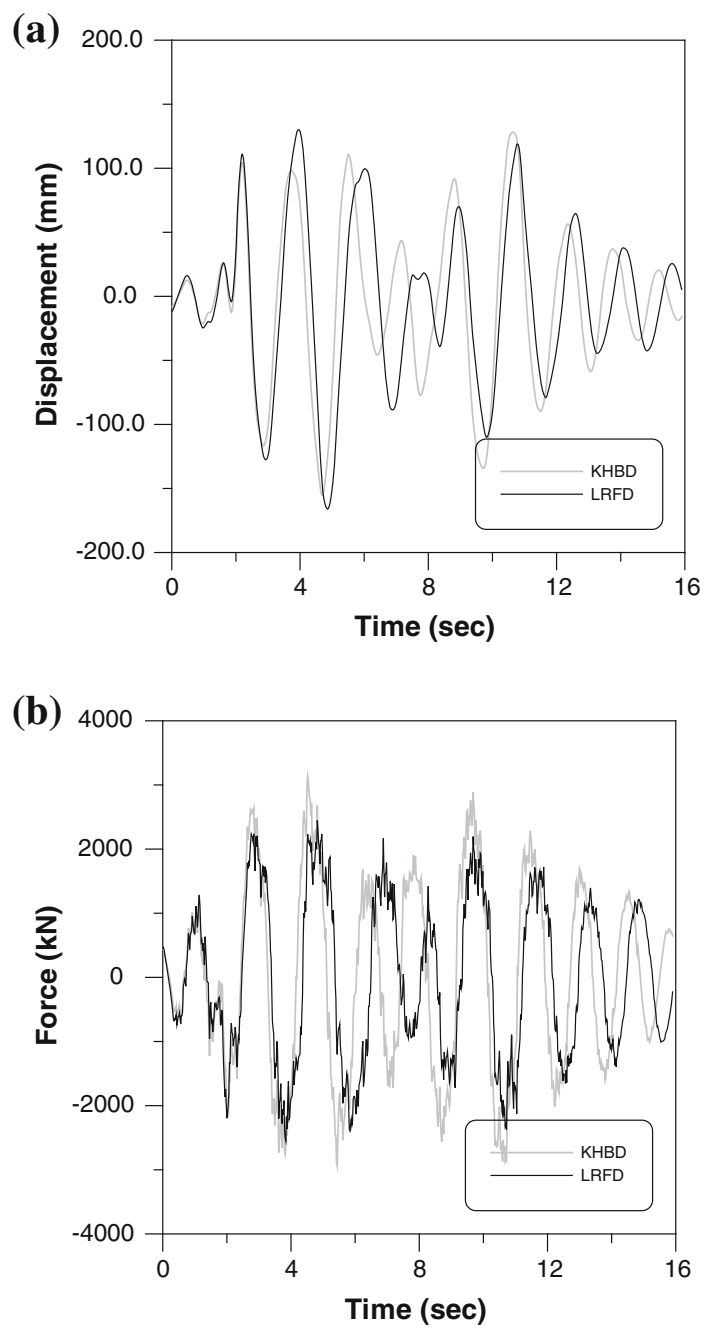

Fig. 13 Response for design example (PGA $0.5 \mathrm{~g}$ ): a displacement; and $\mathbf{b}$ force.

can be used as basic data for preparing the more rational and economical design codes for the totally prefabricated bridge substructure.

\section{Conclusions}

This study presents the comparison of totally prefabricated bridge substructure system designed according to Korea Highway Bridge Design (KHBD) and AASHTOLRFD. From the results of the design comparison and nonlinear analytical studies, the following conclusions were reached.

1. As noted in the results of design comparison, as much as $9 \%$ smaller costs for prefabricated bridge substructure are possible using AASHTO-LRFD versus KHBD. This case occurred because the wind load combinations in AASHTO-LRFD is consider to small compare to KHBD. The load combination shows a $30 \%$ benefit using AASHTO-LRFD versus KHBD and collision loads were not included.

2. The proposed constitutive model and numerical analysis describe with acceptable accuracy the inelastic behavior 

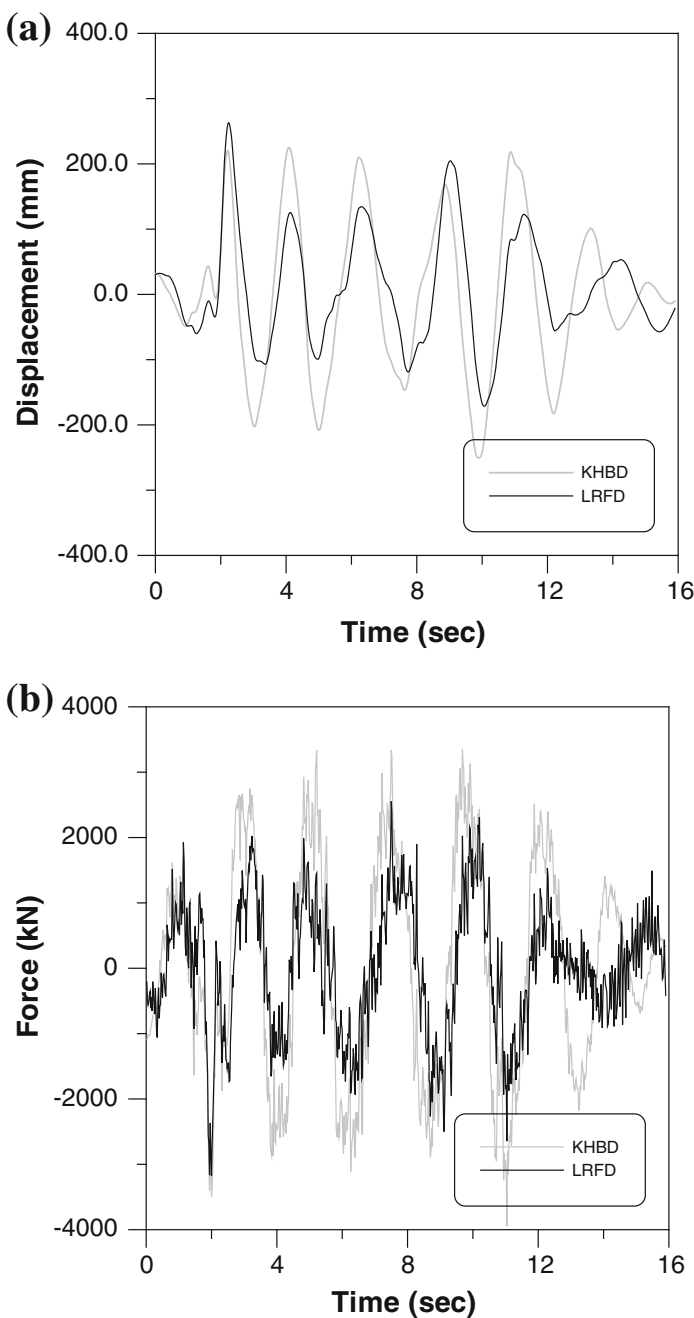

Fig. 14 Response for design example (PGA 0.9 g): a displacement; and $\mathbf{b}$ force.
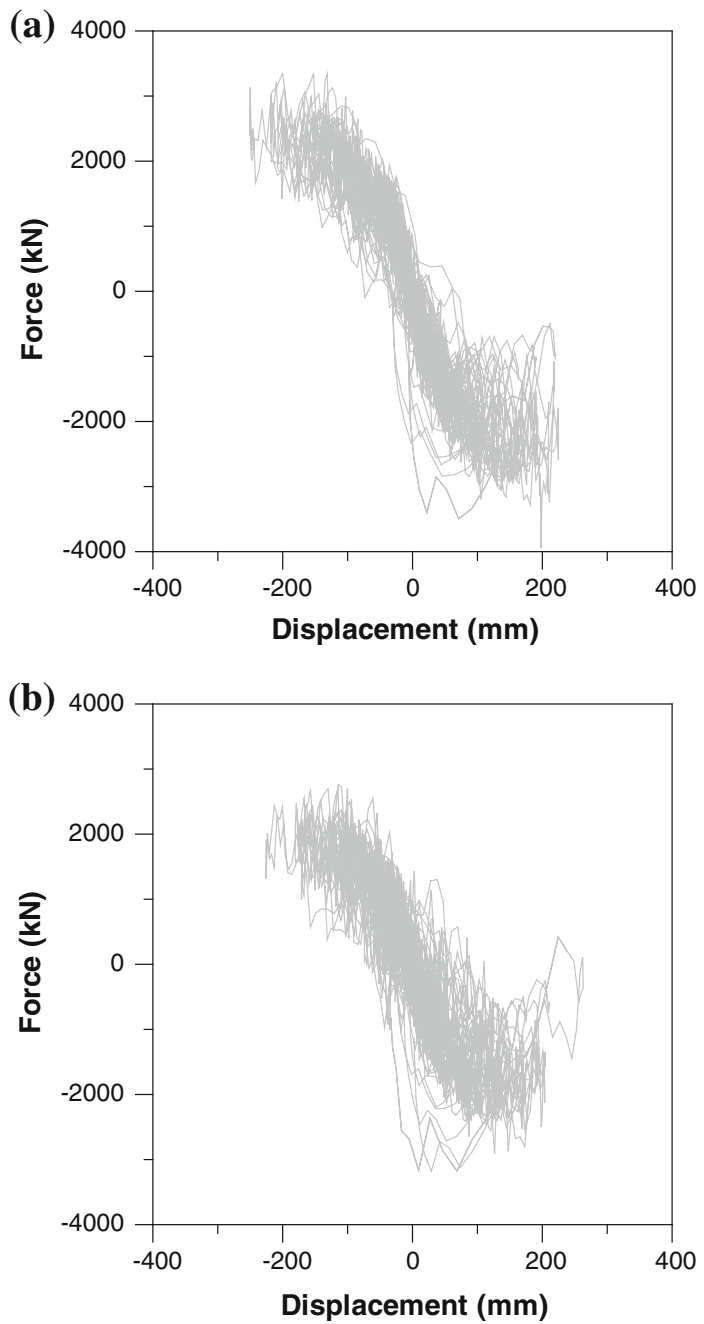

Fig. 15 Restoring force for design example: a KHBD; and b AASHTO-LRFD.

Table 3 Description of performance levels (Kim et al. 2007).

\begin{tabular}{c|c|c|c|c}
\hline Performance level & Service & Repair & \multicolumn{2}{|c}{ Damage } \\
\cline { 3 - 5 } & Fully service & Limited epoxy injection & Hairline cracks & 0.1 \\
\hline \hline Fully operational & Limited service & $\begin{array}{c}\text { Epoxy injection concrete } \\
\text { patching }\end{array}$ & $\begin{array}{c}\text { Open cracks concrete } \\
\text { spalling }\end{array}$ & 0.4 \\
\hline Stability & Not useable & $\begin{array}{c}\text { Replacement of damaged } \\
\text { section }\end{array}$ & $\begin{array}{c}\text { Bar buckling/fracture core } \\
\text { crushing }\end{array}$ & 0.75 \\
\hline
\end{tabular}

of the totally prefabricated bridge substructure when subjected to earthquake conditions. This method may be used for the seismic analysis and design of prefabricated bridge substructure system.

3. The use of load-moment interaction diagrams as a design aid should provide a quick and economical solution for the design of totally prefabricated bridge substructure when a complete computer solution is not available.
4. The importance of identifying and evaluating the adequacy of simulation methods is an important and necessary step in applying performance-based assessment techniques for assessing new, enhanced performance systems such as the self-centering system herein under consideration.

5. Additional parametric research is needed to refine and confirm design details, especially for actual detailing employed in the field. 


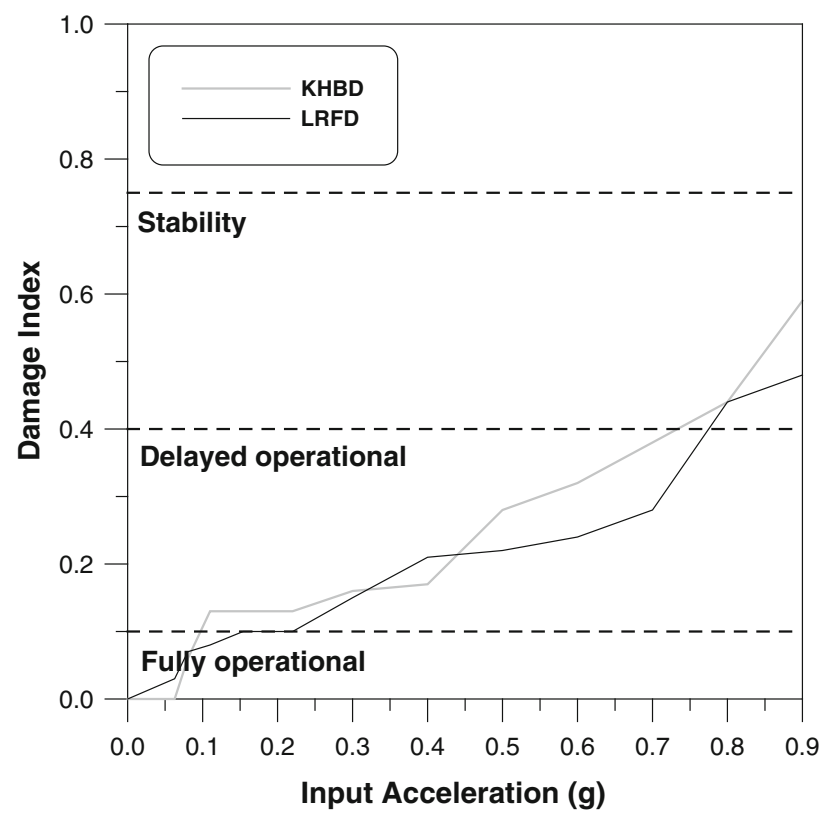

Fig. 16 Assessment for performance level for design example.

Table 4 Failure criterion and damage index (Kim et al. 2007).

\begin{tabular}{c|c|c|c}
\hline Material & Type of failure & $\begin{array}{c}\text { Failure criterion } \\
\left(\varepsilon_{c u} \text { or } \varepsilon_{t u}\right)\end{array}$ & $\begin{array}{c}\text { Damage index } \\
\left(D I_{\text {compressive }} \text { or }\right. \\
\left.D I_{\text {tensile }}\right)\end{array}$ \\
\hline \hline Concrete & $\begin{array}{c}\text { Compressive } \\
\text { and shear }\end{array}$ & $0.004+\frac{1.4 \rho_{f_{f} c_{s m} \varepsilon_{s m}}}{f_{c c}^{\prime}}$ & $1-f t g_{c}\left(\frac{2 \varepsilon_{c u}-\varepsilon_{c s}}{2 \varepsilon_{c u}}\right)^{2}$ \\
\hline Steel & Tensile & 0.10 & $1.20\left(\frac{\varepsilon_{t s}}{2 f t g_{r} \varepsilon_{t u}}\right)^{0.67}$ \\
\hline
\end{tabular}

$\rho_{s}$ transverse confining steel ratio, $f_{y h}$ yield stress of the confining steel, $\varepsilon_{s m}$ steel strain at maximum tensile stress, $f_{c c}^{\prime}$ confined concrete compressive strength, $f g_{c}$ fatigue parameter for concrete, $f t_{r}$ fatigue parameter for reinforcing bars, $\varepsilon_{c s}$ compressive strain in analysis step, $\varepsilon_{t s}$ tensile strain in analysis step, $\varepsilon_{c u}$ ultimate strain of concrete, $\varepsilon_{t u}$ ultimate strain of reinforcing bars

\section{Open Access}

This article is distributed under the terms of the Creative Commons Attribution License which permits any use, distribution, and reproduction in any medium, provided the original author(s) and the source are credited.

\section{References}

AASHTO. (2007). AASHTO LRFD bridge design specifications (4th ed.).

Applied Technology Council (ATC 32). (1996). Improved seismic design criteria for California bridges: Provisional recommendations.

Billington, S. L., Barnes, R. W., \& Breen, J. E. (2001). Alternative substructure systems for standard highway bridges. Journal of Bridge Engineering, ASCE, 6(2), 87-94.
Billington, S. L., \& Yoon, J. K. (2004). Cyclic response of unbonded posttensioned precast columns with ductile fiberreinforced concrete. Journal of Bridge Engineering, ASCE, 9(4), 353-363.

Cheng, C.-T. (2008). Shaking table tests a self-centering designed bridge substructure. Engineering Structures, 30(12), 3426-3433.

Chou, C.-C., \& Chen, Y.-C. (2006). Cyclic tests of post-tensioned precast CFT segmental bridge columns with unbonded strands. Earthquake Engineering and Structural Dynamics, 35, 159-175.

Dawood, H., EIGawady, M., \& Hewes, J. (2012). Behavior of segmental precast posttensioned bridge piers under lateral loads. Journal of Bridge Engineering, ASCE, 17(5), 735-746.

EIGawady, M. A., \& Dawood, H. M. (2012). Analysis of segmental piers consisted of concrete filled FRP tubes. Engineering Structures, 38, 142-152.

Federal Emergency Management Agency. (1997). NEHRP guidelines of the seismic rehabilitation of buildings, FEMA 273. Washington, DC: FEMA.

Hewes, J. T. (2002). Seismic design and performance of precast concrete segmental bridge columns. Ph.D. Dissertation, Department of Structural Engineering, University of California, San Diego, CA.

Hilber, H. M., Hughes, T. J. R., \& Taylor, R. L. (1977). Improved numerical dissipation for time integration algorithms in structural dynamics. Earthquake Engineering and Structural Dynamics, 5, 282-292.

Hughes, T. J. R. (1987). The finite element method. Englewood Cliffs, NJ: Prentice-Hall.

Kim, T.-H., Kim, Y.-J., Kang, H.-T., \& Shin, H. M. (2007). Performance assessment of reinforced concrete bridge columns using a damage index. Canadian Journal of Civil Engineering, 34(7), 843-855.

Kim, T. -H., Kim, Y. -J., \& Shin, H. M. (submitted). Performance assessment of precast concrete pier cap system. Computers and Concrete.

Kim, T.-H., Lee, H.-M., Kim, Y.-J., \& Shin, H. M. (2010a). Performance assessment of precast concrete segmental bridge columns with a shear resistant connecting structure. Engineering Structures, 32(5), 1292-1303.

Kim, T.-H., Park, J.-G., Kim, Y.-J., \& Shin, H. M. (2008). A computational platform for seismic performance assessment of reinforced concrete bridge piers with unbonded reinforcing or prestressing bars. Computers and Concrete, 5(2), 135-154.

Kim, T.-H., Park, S.-J., Kim, Y.-J., \& Shin, H. M. (2010b). Performance assessment of precast segmental PSC bridge columns with precast concrete footings. Magazine of Concrete Research, 62(11), 773-787.

Maekawa, K., Pimanmas, A., \& Okamura, H. (2001). Nonlinear mechanics of reinforced concrete. London, UK: SPON Press.

Mander, J. B., Priestley, M. J. N., \& Park, R. (1988). Theoretical stress-strain model for confined concrete. Journal of Structural Engineering, ASCE, 114(8), 1804-1826.

Ministry of Construction and Transportation. (2005). Korea highway bridge design code. 
Murla-Vila, D., Sanchez-Ramirez, A. R., Huerta-Carpizo, C. H., \& Fernandez-Sola, L. R. (2012). In-situ test of a precast pier of an elevated viaduct in Mexico City. In 15th world conference on earthquake and engineering, Lisbon, Portugal, USB.

Ou, Y.-C., Chiewanichakorn, M., Aref, A. J., \& Lee, G. C. (2007). Seismic performance of segmental precast unbonded posttensioned concrete bridge columns. Journal of Structural Engineering, ASCE, 133(11), 1636-1647.

Rouse, J. M. (2004). Behavior of bridge piers with ductile fiber reinforced hinge regions and vertical, unbonded post-tensioning. Ph.D. Dissertation, Department of Civil Engineering, Cornell University, Ithaca, NY.

Sun, Y. P., \& Sakino, K. (2000). A comprehensive stress-strain model for high strength concrete confined by circular transverse reinforcement. In The 6th ASCCS international conference on steel-concrete composite structures, University of Southern California (pp. 1067-1074).

Taylor, R. L. (2000). FEAP - A finite element analysis program, version 7.2 users manual (Vols. 1 and 2). London, UK: Butterworth.

Wang, J.-C., Ou, Y.-C., Chang, K.-C., \& Lee, G. C. (2008). Large-scale seismic tests of tall concrete bridge columns with precast segmental construction. Earthquake Engineering and Structural Dynamics, 37, 1449-1465.

Xiao, J., Huang, X., \& Shen, L. (2012). Seismic behavior of semi-precast column with recycled aggregate concrete. Construction and Building Materials, 35, 988-1001.

Yamashita, R., \& Sanders, D. (2009). Seismic performance of precast unbonded prestressed concrete columns. $A C I$ Structural Journal, 106(6), 821-830. 